\title{
Authors' Response to the Letter from Davis and Huisman Commenting on "Potato Early Dying: Management Challenges in a Changing Production Environment"
}

In our November 2002 feature article entitled "Potato early dying: Management challenges in a changing production environment" (18), we presented a global view of this disease and stressed that innovative and forward-thinking research on disease management will be essential for the North American potato industry to thrive in a production environment that is continually changing. We summarized published research on pathogen biology and genetic variation, role of root-lesion nematodes, transmission by seed tubers, and various management strategies, including host resistance, soil fumigation, crop rotation, and the application of organic amendments, reviewing work done across the United States and Canada as well as some from Europe, Israel, and other countries.

In rebutting our comments in their "Letter to the Editor", we believe that Davis and Huisman have taken a rather narrow, regional view of the situation, based primarily on their experience in southern Idaho. Among the 24 published works they cite in support of their comments, only half are refereed journal articles, one of which was published after our article appeared. The rest are abstracts, books, or trade publications. Furthermore, Davis is the lead author on 13 of the 24 works cited and coauthor on four more. We are concerned that their objections to our article may reflect mostly their opinion of the situation in southern Idaho rather than a wideranging perspective of the disease.

At the end of our article, we put forth five key areas of research that we believe warrant specific attention. In their summary, they indicated all these were unimportant and that future research should be focused primarily on using green manures and nutrition to manage the disease. We were invited to prepare a response to their rebuttal; therefore, we first consulted with four potato pathologists who currently are active in the Pacific Northwest and together are very knowledgeable about potato early dying in that area and its effective management. They are Dr. Dennis Johnson and Dr. Debra Inglis, Washington State University; Mr. Philip Hamm, Oregon State University; and Dr. Jeff Miller, University of Idaho. The responses that follow are our collective opinions.

The first issue put forth by Davis and Huisman is that "proper management of plant nutrition has a major impact on Verticillium wilt severity". We chose not to include this subject among the disease management topics we discussed because there is very little published evidence that this is a practical and useful management tactic outside the work of Dr. Davis and his colleagues $(8,9)$. In fact, recent studies in eastern Canada do not support this approach (14). Although we agree that a deficit of nitrogen, and perhaps phosphorus, may be associated with increased disease severity, this rarely happens in commercial potato production where fertilizers are applied liberally. All four potato pathologists that we contacted indicated that nutrition management is not being used by commercial growers in the Pacific Northwest as a specific management tactic for potato early dying, primarily because growers already are trying to optimize yields through precision fertility.

In our article, we discussed the use of genetic host resistance for management of Verticillium spp. We cited the example that, despite the considerable research done in many potato breeding programs, of the seven cultivars most commonly grown in North America in 2000 that together accounted for $75 \%$ of the commercial acreage, only one, Ranger Russet, had any level of resistance. Davis and Huisman countered that we "ignore the fact that, since 1984, a series of successful potato cultivars possessing varying levels of either resistance or tolerance to Verticillium wilt have been released." While this surely is true (they cite Alturus, a 2003 release that became available after our article was published), it is undeniable that the majority of the North American potato acreage still is being planted to Verticillium spp.susceptible cultivars. The potato pathologists that we contacted agreed that currently available commercial cultivars have either no resistance or only moderate levels of partial resistance. For optimum yield, they must be used in conjunction with other disease management practices. Our point was that major breakthroughs, using modern molecular-based breeding technologies, will be required to bring host resistance to the fore as a primary tactic for management of this disease.

Davis and Huisman were quite critical of our discussion regarding the use of green manure crops to manage this disease, particularly our statement that several years of green manure production are required. They state that their recent work now shows that "once a suppressive effect has been established in a soil, a single green manure can be sufficient to maintain or re-establish the effect". However, they cite only their 2003 abstract (5) and one proceedings paper (6) to verify that assertion. There is no question that this research team has done some noteworthy research in this area. In fact, in our article, we reprinted a picture from one of their articles (7) showing the dramatic effects of 3 years of plowing down and incorporating a green manure crop on reduction of Verticillium wilt on potato. However, we also reviewed published work on the use of organic amendments that was done in several U.S. states and Canada, and these studies showed varying results $(1,11,12,16,19,20)$. Davis and Huisman state that "the use of green manures in a crop rotation program can be an effective management tool for minimizing the economic damage from Verticillium wilt." Although this may be valid in the future (and we listed that as a key area for future research), our conversations with potato pathologists in the Pacific Northwest indicated that, in the absence of long-term replicated studies from several production areas, it would be difficult to support this presently as a general management recommendation for potato early dying. All four agreed that research on green manure crops shows great promise, but the tactic is not generally accepted commercially at this point in time, and several factors remain that may limit the economic viability of including green manure crops in a commercial rotation with potato. We believe that the work of Davis and Huisman in this area needs to be expanded and confirmed in other production areas before it could be adopted widely in commercial production.

Among the comments made by Davis and Huisman are some where we believe they missed the points we were trying to make. With regard to our comments on assays to estimate Verticillium populations in soil, they objected to our statement that "Plating soil on semi-selective media has been shown to be inconsistent and unreliable for estimating soil populations". The article we cited (21), of which they were among the multiple authors, concluded that "wet plating assays are less accurate than dry plating assays", but also emphasized that there was "substantial variation noted within the two assay types." Regardless of the perceived efficacy of this traditional procedure, the main point that we made was that newer "DNA-based technologies hold promise for providing a more accurate and repeatable diagnostic tool for 
measuring soil populations". We hope these authors would not have us totally ignore all the new molecular technologies that are revolutionizing pathogen diagnostics. Surely this is a fertile area for research that may lead to improved, highly accurate techniques for estimating Verticillium populations in soil.

Another area where they missed our point was the importance of seed tuber infection by Verticillium spp. They refuted our contention that this was an important area for future research because "given the current state of the art of the potato seed programs, development of clean stock probably is not practical" and "Given the wide global distribution of the pathogen and its presence in all major production areas, it is too late to prevent its introduction." Our assertion was that "Studies are warranted to determine the significance of seedborne inoculum of Verticillium in current-season disease expression and tuber yield reduction." If one goes to the expense and effort of managing soil populations of Verticillium spp. by fumigation, or even green manures, how important is the fact that the seed tubers subsequently planted in that soil already are systemically infected by the pathogen? The importance of seed tuber transmission in currentseason infection is undetermined and we believe it warrants further study. It certainly is possible that future management tactics directed at seed tubers could have a significant impact on the timing of infection, symptom expression, and yield.

Davis and Huisman conclude their comments by taking us to task for using the term "potato early dying" rather than "Verticillium wilt" to describe this disease. Although everyone agrees (and we stated in our article) that Verticillium dahliae or $V$. albo-atrum are the primary causal agents of this disease and are capable of inducing symptoms unilaterally, widespread evidence exists that other pathogens, including root-lesion nematodes, soft-rot bacteria, and several fungi, can interact with Verticillium spp. in some situations $(3,15,22)$. The term "potato early dying" is widespread in the literature over the past 20 years $(2,4,10,11,13,15,17,22)$ and we see no valid reason to object to this well-established term now.

In writing our feature article, our intent was to summarize current knowledge on potato early dying and then identify fertile areas for future research, emphasizing the need to continue development of new management strategies in response to a changing potato-production environment. We discussed how new molecular-based technologies might impact the development of truly resistant cultivars and revolutionize diagnostic techniques. The need for new fungicide chemistries, expanded research into soil suppressiveness, and understanding the role of seed tubers in disease epidemiology also were forefront. In response, Davis and Huisman seem to take comfort that current knowledge is sufficient in all these areas and that "available current management practices can effectively manage this important disease." We believe otherwise.

\section{LITERATURE CITED}

1. Berlanger, I. 1999. Effect of broccoli green manure, soil solarization and isolates of Verticillium dahliae on Verticillium wilt of agronomic and nursery crops. M.S. thesis, Oregon State University, Corvallis.

2. Botseas, D. D., and Rowe, R. C. 1994. Development of potato early dying in response to infection by two pathotypes of Verticillium dahliae and co-infection by Pratylenchus penetrans. Phytopathology 84:275-282.

3. Bowers, J. H., Nameth, S. T., Riedel, R. M., and Rowe, R. C. 1996. Infection and colonization of potato roots by Verticillium dahliae as affected by Pratylenchus penetrans and P. crenatus. Phytopathology 86:614-621.

4. Cappaert, M. R., Powelson, M. L., Christensen, N. W., Stevenson, W. R., and Rouse, D. I. 1994. Assessment of irrigation as a method of managing potato early dying. Phytopathology 84:792-800.

5. Davis, J. R., Huisman, O. C., and Everson, D. O. 2003. Verticillium control and increased yields following continuous potato with a single season of green manure. (Abstr.) Am. J. Potato Res. 81:54.

6. Davis, J. R., Huisman, O. C., Westermann, D. T., Everson, D. O., Sorensen, L. H., and Schneider, A. T. 2000. Alternative approaches for control of Verticillium wilt of potato with sudangrass. Pages 292-295 in: Advances in Verticillium Research and Disease Management. E. C. Tjamos, R. C. Rowe, J. B. Heale, and D. R. Fravel, eds. American Phytopathological Society, St. Paul, MN.

7. Davis, J. R., Huisman, O. C., Westermann, D. T., Hafez, S. L., Everson, D. O., Sorensen, L. H., and Schneider, A. T. 1996. Effects of green manures on Verticillium wilt of potato. Phytopathology 86:444-453.

8. Davis, J. R., Sorensen, L. H., Stark, J. C., and Westermann, D. T. 1990. Fertility and management practices to control Verticillium wilt of the Russet Burbank potato. Am. Potato J. 67:55-65.

9. Davis, J. R., Stark, J. C., Sorensen, L. H., and Schneider, A. T. 1994. Interactive effects of nitrogen and phosphorous on Verticillium wilt of Russet Burbank potato. Am. Potato J. 71:467481.

10. Dobinson, K. F., Harrington, M. A., Omer, M., and Rowe, R. C. 2000. Molecular characterization of vegetative compatibility group $4 \mathrm{~A}$ and 4B isolates of Verticillium dahliae associated with potato early dying. Plant Dis. 84:1241-1245.

11. LaMondia, J. A., Gent, M. P. N., Ferrandino, F. J., Elmer, W. H., and Stoner, K. A. 1999. Effect of compost amendment or straw mulch on potato early dying disease. Plant Dis. 83:361366.

12. Lazarovits, G., Tenuta, M., and Conn, K. L. 2001. Organic amendments as a disease control strategy for soil borne diseases of high-value agricultural crops. Australas. Plant Pathol. 30:111-117.

13. MacGuidwin, A. E., and Rouse, D. I. 1990. Role of Pratylenchus penetrans in potato early dying disease of Russet Burbank potato. Phytopathology 80:1077-1082.

14. Platt, H. W., and Arsenault, W. J. 2001. Management of nitrogen and phosphorus rates does not suppress Verticillium wilt in Yukon Gold Am. J. Potato Res. 78:215-219.

15. Powelson, M. L, and Rowe, R. C. 1993. Biology and management of early dying of potatoes. Ann. Rev. Phytopathol. 31:111-126.

16. Rotenberg, D., and Cooperband, L. 2002. Disease incidence and severity in potatoes grown in composts and paper mill residual. Pages 47-52 in: Proc. Wisc. Annu. Potato Meeting 2002, Stevens Point, WI

17. Rowe, R. C., Davis, J. R., Powelson, M. L., and Rouse, D. I. 1987. Potato early dying: causal agents and management strategies. Plant Dis. 71:482-489

18. Rowe, R. C., and Powelson, M. L. 2002. Potato early dying: Management challenges in a changing production environment. Plant Dis. 86:1184-1193.

19. Subbarao, K. V., and Hubbard, J. C. 1996. Interactive effects of broccoli residue and temperature on Verticillium dahliae microsclerotia in soil and on wilt in cauliflower. Phytopathology 86:1303-1310.

20. Tenuta, M., and Lazarovits, G. 2002. Ammonia and nitrous acid from nitrogenous amendments kill the microsclerotia of Verticillium dahliae. Phytopathology 92:255-264.

21. Termorshuizen, A. J., Davis, J. R., Gort, G., Harris, D. C., Huisman, O. C., Lazarovits, G., Locke, T., Melero-Vara, J. M., Mol, L. Paplomatas, E. J., Platt, H. W., Powelson, M., Rouse, D. I., Rowe, R. C., and Tsror, L. 1998. Interlaboratory comparison of methods to quantify microsclerotia of Verticillium dahliae in soil. Appl. Environ. Microbiol. 64:38463853.

22. Wheeler, T. A., and Riedel, R. M. 1994. Interactions among Pratylenchus penetrans, $P$ scribneri, and Verticillium dahliae in the potato early dying disease complex. J. Nematol. 26:228-234.

Randall C. Rowe, Professor Department of Plant Pathology

The Ohio State University

Wooster, OH 44691

Mary L. Powelson, Professor Emeritus Department of Botany and Plant Pathology Oregon State University

Corvallis, OR 97731

Publication no. D-2004-0902-010 